\title{
Pengenalan Etnobotani melalui Pembuatan Herbarium Kering di Lingkungan Sekolah MI Muhammadiyah Plumbon, Wonogiri
}

Siti Hadiyati Nur Hafida ${ }^{1}$,Arga Prasetya Ariandi ${ }^{2}$, Laela Ismiyatin ${ }^{3}$, Diyah Ayu Wulandari ${ }^{4}$, Novita Reygina $^{5}$, Tri Setyaningsih ${ }^{6}$, Lia Setyawati ${ }^{7}$, Salma Lutfiani Sochiba ${ }^{8}$, Moh Afif Khoirul Amin ${ }^{9}$

${ }_{1,2,3,4,5,6,7,8,9}$ Fakultas Keguruan dan Ilmu Pendidikan, Universitas Muhammadiyah Surakarta, Indonesia

\section{INFORMASI ARTIKEL}

\section{Histori Artikel:}

Submit: 28 April 2020

Revisi: 28 Agustus 2020

Diterima: 30 Agustus 2020

Publikasi: 3 September 2020

Periode Terbit: Desember 2020

\section{Kata Kunci: \\ etnobotani, \\ herbarium, \\ lingkungan, \\ penghijauan}

\section{Correspondent Author:}

Siti Hadiyati Nur Hafida

Fakultas Keguruan dan Ilmu Pendidikan

Universitas Muhammadiyah Surakarta,

Indonesia

Email: nuf.hafida@ums.ac.id

\begin{abstract}
ABSTRAK
Herbarium merupakan suatu eksperimen dari bahan tumbuhan yang telah dimatikan dan diawetkan melalui metode tertentu yang dilengkapi dengan data-data dan manfaat dari tumbuhan tersebut. Ada beberapa tahapan dari pembuatan herbarium, dimulai dari pengumpulan tanaman, pengeringan, pengawetan, dan pembuatan herbarium. Metode yang digunakan adalah metode deskriptif kualitatif. Lokasi yang digunakan di MIM Plumbon, Kecamatan Eromoko. Sasaran penelitian adalah siswa MIM Plumbon. Teknik pengumpulan data menggunakan teknik observasi dan dokumentasi. Hasil penelitian ini adalah (1) herbarium ini termasuk herbarium kering, (2) Tumbuhan yang digunakan dalam herbarium ini antara lain, daun pepaya, daun singkong, daun jambu biji, dan daun seledri, (3) Penyampaian manfaat tanaman obat yang telah dikeringkan unutk di sosialisasikan kepada seluruh warga MIM Plumbon. (4) Tingkat pengetahuan dan perilaku sikap ilmiah tergolong rendah
\end{abstract}

\section{Pendahuluan}

Abad 21 telah mendorong majunya teknologi, salah satunya dalam bidang kesehatan. Berkembangnya alat-alat medis saat ini, juga diimbangi dengan penemuanpenemuan baru terkait dengan penggunaan obat-obat herbal oleh para ahli farmasi (Bibi et al., 2014). Penemuan obat herbal cenderung dipengaruhi oleh sumber daya alam yang ada di lingkungan setempat, sehingga perlu adanya pengenalan lebih lanjut antara manusia di dunia dengan lingkungan tempat tinggal mereka atau disebut dengan Etnobotani. Etnobotani sering diartikan sebagai hubungan masyarakat setempat dengan lingkungan hidupnya, seperti penggunaan tumbuhan untuk makanan, perlindungan, pakaian, obatobatan, dan keperluan lainnya (Nisyaputri et al., 2018). Saat ini tidak sedikit masyarakat yang sudah menggunakan tumbuh-tumbuhan untuk memenuhi kebutuhan hidupnya. Para ahli juga telah berupaya selalu memberikan inovasi yang memanfaatkan kebudayaan dan kekayaan alam lokal, termasuk sumber daya tumbuhannya. Etnobotani adalah suatu bidang ilmu yang mempelajari interaksi antara manusia dengan alam, termasuk di dalamnya sistem pengetahuan tentang sumber daya tumbuhan.

Manusia merupakan individu yang sangat mudah menyesuaikan diri dengan kondisi lingkungannya (Nurfadila, Iqbal, \& Pitopang, 2019). Dalam upaya untuk menyesuaikan diri, seringkali manusia memanfaatkan pengetahuan tradisional untuk memenuhi kebutuhannya. Pengetahuan tradisional ini perlu terus dikembangkan agar tidak hilang di tengah-tengah modernisasi saat ini (Kusharsono, Pandjaitan, \& Hatta, 2013). Pengetahuan 
e-ISSN 2716-0327

doi: 10.23917/bkkndik.v2i2.10776

etnobotani menjadi salah satu pengetahuan yang perlu diberikan kepada siswa agar siswa mampu memanfaatkan lingkungan dengan sebaik mungkin. Pengetahuan etnobotani dapat membantu siswa untuk mengetahui jenis dan manfaat tumbuhan yang dapat digunakan dalam kehidupannya (Darma, Priyadi, \& Iryadi, 2019). Etnobotani akan berkaitan erat dengan Mata Pelajaran Biologi, dan seringkali siswa mengalami kesulitan dalam mata pelajaran tersebut karena banyaknya istilah asing. Adanya permasalahan tersebut mendorong perlu adanya kemudahan bagi siswa untuk memahami etnobotani dengan lebih baik.

Adanya pemahaman etnobotani dapat membantu upaya konservasi sumber daya hutan (Tamin, Anggraini, \& Ulfa, 2017). Kebutuhan terhadap pengetahuan etnobotani saat ini semakin meningkat akibat adanya ketergantungan makhluk hidup terhadap tumbuhan yang semakin besar (Hakim., 2014). Permasalahan yang semakin kompleks akan mendorong siswa untuk meningkatkan dan mengembangkan dirinya sendiri maupun orang lain melalui ilmu pengetahuan dan teknologi. Pengetahuan generasi muda menjadi kunci berkembangnya etnobotani di masa depan. Tidak hanya mengetahui tentang berbagai jenis tumbuhan baik lokal maupun nasional, akan tetapi juga memahami kegunaan dan fungsi tumbuhan tersebut untuk meningkatkan kebutuhan hidup masyarakat saat ini dan masa yang akan datang. Penggunaan tumbuhan sebagai obat herbal atau hanya untuk meningkatkan imunitas tubuh merupakan hal yang sudah tidak asing lagi bagi masyarakat oleh karena itu, pemahaman mengenai etnobotani pada siswa sangat penting.

Banyak masyarakat di daerah pedesaan yang menggunakan pekarangannya untuk ditanami tumbuhan yang dipercaya dapat menyembuhkan penyakit tertentu (Nisyaputri et al., 2018). Selain tumbuhan obat tersebut mudah ditemukan, harganya juga relatif murah dibandingkan dengan biaya untuk periksa ke rumah sakit. Bahkan semua bagian tumbuhan dapat digunakan sebagai obat sesuai dengan jenis tumbuhannya, meliputi: bunga, daun, batang, akar, buah, maupun biji.

Salah satu cara untuk meningkatkan pengetahuan generasi muda tentang pemanfaatan tumbuhan dapat dilakukan melalui kegiatan herbarium. Herbarium merupakan spesimen tumbuhan yang telah diawetkan dan dapat dijadikan sebagai media pembelajaran (Afifah, Sudarmin, \& Widianti, 2014; Dikrullah, Rapi, \& Jamilah,
Buletin KKN Pendidikan, Vol. 2, No. 2, Desember 2020

2018). Hal tersebut sesuai dengan Suminar, Herlambang, \& Syarif (2018) yang menyatakan bahwa herbarium merupakan material pokok yang bermanfaat saat mempelajari sistematis tumbuhan. Dikrullah et al., (2018) menyatakan bahwa herbarium dapat digunakan untuk membantu identifikasi tumbuhan dengan keunggulan mudah dibawa dan praktis digunakan.

Tujuan koleksi herbarium yaitu untuk memperkenalkan etnobotani terhadap anak-anak dan sebagai penelitian tindak lanjut oleh para ahli (Greve et al., 2016). Herbarium memiliki dua jenis, yaitu herbarium kering (daun, akar, bunga, batang), dan herbarium basah (buah-buahan). Herbarium yang dapat dijadikan sebagai media pembelajaran adalah herbarium kering. Herbarium kering merupakan koleksi tumbuhan yang telah dikeringkan dan disusun pada sebuah kertas serta diberi keterangan terkait dengan spesimen tersebut (Dikrullah et al., 2018). Herbarium kering akan mendorong siswa untuk semakin berkreasi terhadap jenis-jenis tumbuhan (Husain et al., 2019).

Saat ini, etnobotani sudah berevolusi tidak hanya mendokumentasikan penggunaan tanaman oleh masyarakat, tetapi sudah fokus pada pemahaman mengapa dan bagaimana tanaman tersebut digunakan. Oleh sebab itu, etnobotani sangat penting untuk dipahami dan dipelajari oleh generasi muda di berbagai tingkatan pendidikan mulai dari sekolah dasar hingga perguruan tinggi, salah satunya melalui kegiatan belajar praktik secara langsung yaitu pelatihan membuat herbarium kering. Herbarium kering lebih mudah dibuat daripada herbarium basah, karena tumbuhan atau spesimen yang digunakan hanya dikeringkan saja, dan aman dilakukan oleh anak-anak. Kegiatan pelatihan membuat herbarium kering di sekolah sangat efektif dan efisien untuk memperkenalkan tumbuhan dari lingkungan sekitar kepada siswa untuk memperdalam pelajaran etnobotani (biologi tumbuhan) sesuai dengan kurikulum sekolah (Mertha, Idrus, Ilhamdi, \& Zulkifli, 2018).

Pembelajaran yang mengintegrasikan lingkungan seperti herbarium kering sangat bermanfaat untuk membantu siswa dalam mengidentifikasi tumbuhan dan mampu mendorong pembelajaran aktif dan menyenangkan (Mertha et al., 2018). Kegiatan pelatihan teknik pembuatan herbarium kering telah dilaksanakan di lingkungan MIM Plumbon yang terletak di lingkungan Plumbon, Desa Ngadirejo, Eromoko, wonogiri, Jawa Tengah. Lingkungan sekolah yang kaya akan jenis-jenis 
tumbuhan dan budaya masyarakat yang memiliki kepercayaan terhadap obat tradisional, serta antusias siswa untuk meneruskan dan mengembangkan budaya tersebut. Oleh karena itu, kegiatan herbarium kering sangat tepat untuk di lakukan. Selain dapat meningkatkan pengetahuan, kegiatan ini mendorong peserta didik untuk berfikir kritis, aktif, dan kreatif dalam memanfaatkan kekayaan lokal baik untuk kepentingan pribadi, keluarga, maupun masyarakat setempat. Sehingga, tidak dapat di pungkiri bahwa pendalaman disiplin ilmu etnobotani sebenarnya dapat dilakukan mulai dari sekolah dasar.

\section{Metode Pelaksanaan}

Metode yang digunakan pada kegiatan KKN-Dik FKIP UMS ini adalah pelatihan kepada siswa MIM Plumbon, yakni kelas 3 sampai dengan kelas 6. Pelatihan ini berawal dari sosialisasi tentang pengenalan herbarium, yakni menjelaskan metode herbarium, alat dan bahan yang akan digunakan, kegunaan dari alat dan bahan, lalu pelaksanaan pembuatan herbarium di lingkungan sekolah MIM Plumbon dengan melakukan penyemprotan alkohol pada spesimen dan dilanjutkan dengan pengepresan, memberi label pada tumbuhan serta pengeringan menggunakan sinar matahari, dan yang terakhir yaitu presentasi hasil pembuatan herbarium yang ditekankan untuk menjelaskan metode yang telah dilakukan serta manfaat dari tumbuhan yang digunakan sebagai bahan obat herbal. Kegiatan presentasi ini dilakukan secara perwakilan per kelas kepada seluruh siswa kelas 3 sampai dengan kelas 6 di lingkungan MIM Plumbon.

\section{Hasil Pelaksanaan dan Pembahasan}

Kegiatan pengabdian di MIM Plumbon Eromoko berupa kegiatan "Pengenalan Etnobotani Melalui Pembuatan Herbarium Kering di MI Muhammadiyah Plumbon" melalui kegiatan pengenalan dan pelatihan kepada siswa kelas 3 sampai 6. Pelaksana kegiatan pengabdian ini adalah Tim KKN-Dik FKIP UMS. Berdasarkan masalah yang diuraikan di MIM Plumbon, maka kegiatan yang dilaksanakan dibagi menjadi beberapa bagian, yaitu:

\section{a. Sosialisasi Herbarium}

Herbarium adalah suatu tumbuhan yang diawetkan melalui metode tertentu, kegiatan herbarium yang dilaksanakan oleh Tim KKN-Dik FKIP UMS menggunakan metode herbarium kering. Herbarium kering yaitu pengawetan yang dilakukan secara pengeringan yang dilakukan dengan penyemprotan alkohol pada tumbuhan, dan disertai dengan pengepresan, pemberian label, dan dijemur menggunakan sinar matahari. Pada kegiatan sosialisasi herbarium siswa MIM Plumbon, tampak sangat antusias dan semangat dalam pengenalan herbarium serta alat dan bahan apa saja yang akan segera dilakukan.

Sosialisasi herbarium di MIM Plumbon dilakukan secara klasikal, yaitu penyampaian materi, semua siswa mengikuti materi yang disampaikan dengan saksama. Sebelum dilakukannya kegiatan siswa masih cenderung kurang mengetahui. Hal tersebut terlihat ketika dilakukan sosialisasi herbarium. Sosialisasi pembuatan herbarium yang dilakukan oleh tim KKN-Dik FKIP UMS adalah sebagai berikut: Langkah 1: pengenalan atau sosialisasi herbarium; Langkah 2: pembagian daun tanaman yang memiliki manfaat sebagai obat herbal yang akan dibawa per kelas yaitu kelas 3 daun papaya, kelas 4 daun singkong, kelas 5 daun jambu biji, dan kelas 6 daun seledri; Langkah 3: pengenalan alat dan bahan yang akan digunakan pada pembuatan herbarium. Adapun alat yang akan digunakan yaitu gunting, koran bekas, laban bening, plastik bening, botol semprotan. Bahan yang digunakan yaitu daun papaya, daun singkong, daun jambu biji, daun seledri, alkohol 70\%, dan tissue.

Kegiatan sosialisasi herbarium, siswa MIM Plumbon berdampak pada peningkatan pengetahuan herbarium. Hal tersebut terbukti dari lancarnya sosialisasi pembuatan herbarium. Sosialisasi pembuatan herbarium bertujuan melatih keterampilan atau sikap ilmiah siswa sejak dini. Siswa MIM Plumbon menjadi sasaran utama karena diharapkan dapat menyampaikan informasi tentang herbarium pada keluarga dan masyarakat.

\section{b. Pembuatan Herbarium}

Masa sekolah dasar merupakan masa dimana anak lebih banyak memahami teori pada materi pembelajaran. Hal tersebut, membuat anak usia sekolah belum memiliki keterampilan praktikum dan sikap ilmiah. Kegiatan pembuatan herbarium di MIM Plumbon, yaitu pengawetan yang dilakukan secara pengeringan yang dilakukan dengan penyemprotan alkohol pada tumbuhan, dan disertai dengan pengepresan, pemberian label, dan dijemur menggunakan sinar matahari, di respons baik oleh siswa MIM Plumbon.

Pada saat melakukan pembuatan herbarium kering oleh siswa MIM Plumbon di lingkungan sekolah, siswa dapat melakukan teknik pengambilan tumbuhan yang 
baik, penyemprotan dengan alkohol, dan tata cara lain sehingga siswa MIM Plumbon terlihat sangat aktif. Hal tersebut terlihat saat melakukan praktik pengepresan spesimen hasil koleksi yang akan dikeringkan dan cara mengawetkan spesimen yang akan di jemur untuk 3 hari seperti pengawetan herbarium yang sudah dijelaskan.

Setelah tim KKN-Dik FKIP UMS sosialisasi cara pengawetan tanaman dan penyemprotan alkohol dengan benar sesuai dengan tata cara, dan ada beberapa pertanyaan yang muncul seperti manfaat dari alkohol dan seberapa banyak alkohol yang akan digunakan. Pada pembuatan herbarium setelah penyemprotan alkohol, dilanjutkan dengan perekatan dan pengepresan tanaman yang telah disemprot dan kering pada kertas koran dan pemberian label. Pada saat kegiatan berlangsung, pendampingan dilakukan tim KKN-Dik FKIP UMS untuk memberikan bimbingan pada siswa agar proses tersebut dilakukan dengan baik dan benar. Siswa banyak mendapat pengetahuan berkaitan dengan pembuatan herbarium. Setiap kelas akan mempresentasikan herbarium yang sudah dilakukan per kelas masing-masing di lingkungan sekolah MIM Plumbon yang di amati dengan saksama oleh kelas lain dan guru MIM Plumbon.

\section{c. Presentasi Herbarium (Pemanfaatan Tanaman Obat)}

Pada kegiatan presentasi hasil herbarium, siswa dapat mengetahui tentang herbarium dan mendapat pengalaman tentang tata cara pembuatan herbarium. Siswa secara langsung dapat menumbuhkan sikap ilmiah dengan adanya kegiatan herbarium dan identifikasi tanaman obat herbal yang sudah didapatkan oleh per kelas masing-masing. Kegiatan ini menjadi menyenangkan dan siswa mengetahui manfaat dari daun tanaman yang merupakan obat herbal alami. Melalui latihan ini para siswa secara langsung dapat mempraktekkan cara pembuatan herbarium dengan metode kering, kegiatan seperti ini sangat penting dalam pembelajaran di sekolah.

Hasil praktik menunjukkan bahwa siswa siswi MIM Plumbon saat mempresentasikan hasil herbarium sangat lancar menjelaskan metode herbarium kering dan mengetahui manfaat dari tanaman obat dari masing-masing kelas. Pengenalan etnobotani Melalui Pembuatan herbarium kering di MIM Plumbon dan presentasi hasil herbarium dengan menjelaskan manfaat daun tanaman, siswa telah memahami cara pembuatan herbarium serta menumbuhkan sikap ilmiah di sekolah MIM Plumbon. Tidak hanya mengikut kegiatan tetapi mengetahui makna atau fungsi dari kegiatan herbarium, serta tidak hanya menghafal pembelajaran di kelas yang membuat jenuh dan tidak kreatif. Pengalaman dalam kegiatan ini sangat membantu mempelajari keanekaragaman hayati di sekolah dan mengetahui manfaat dari berbagai tanaman yang ternyata menjadi mudah dengan adanya herbarium.

\section{Simpulan}

Dari hasil pengamatan yang telah dilakukan di MIM Plumbon, dapat diketahui bahwa tingkat pengetahuan siswa pada pembuatan herbarium dan perilaku sikap ilmiah tergolong rendah. Terutama pada saat dilakukannya kegiatan pembuatan herbarium. Melalui kegiatan herbarium yang telah diberikan dapat mengedukasi sekaligus menambah sikap ilmiah siswa.

\section{Daftar Pustaka}

Afifah, N., Sudarmin, \& Widianti, T. (2014). Efektivitas Penggunaan Herbarium dan Insektarium pada Tema Klasifikasi Makhluk Hidup sebagai Suplemen Media Pembelajaran IPS Terpadu Kelas VII MTs. USEJ - Unnes Science Education Journal, 3(2), 494-501. https://doi.org/10.15294/usej.v3i2.3346

Bibi, T., Ahmad, M., Tareen, R. B., Tareen, N. M., Jabeen, R., Rehman, S.-U., ... Yaseen, G. (2014). Ethnobotany of medicinal plants in district Mastung of Balochistan province-Pakistan. Journal of Ethnopharmacology, 157, 79-89.

Darma, I. D. P., Priyadi, A., \& Iryadi, R. (2019). Studi Etnobotani Masyarakat di Sekitar Kawasan Hutan Bedugul Bali. BIOTROPIC The Journal of Tropical Biology, $3(2)$. https://doi.org/https://doi.org/10.29080/biotropic.2019.3.2.96-104

Dikrullah, Rapi, M., \& Jamilah. (2018). Pengembangan Herbarium Book sebagai Media Pembelajaran Biologi pada Mata Kuliah Struktur Tumbuhan Tinggi. Jurnal Biotek, 6(1), 15-25. https://doi.org/10.24252/jb.v6il.4426

Greve, M., Lykke, A. M., Fagg, C. W., Gereau, R. E., Lewis, G. P., Marchant, R., ... Svenning, J.-C. (2016). Realising the potential of herbarium records for conservation biology. South African Journal of Botany, 105, 317-323.

Hakim., L. (2014). Etnobotani dan Manajemen KebunPekarangan Rumah: Ketahanan Pangan, Kesehatan dan Agrowisata. Retrieved from https://biologi.ub.ac.id/wp-content/uploads/2015/11/ETNOBOTANI-dan-MANAJEMENKEBUN-PEKARANGAN-RUMAH.pdf 
Husain, F., Wicaksono, H., Luthfi, A., Wijaya, A., Prasetyo, K. B., \& Wahidah, B. F. (2019). Berbagi Pengetahuan tentang Herbarium: Kolaborasi Dosen, Guru dan Siswa di MA Al-Asror Patemon Gunungpati. Puruhita, 1(1), 76-84. Retrieved from https://journal.unnes.ac.id/sju/index.php/puruhita/article/view/28652/12533

Kusharsono, S., Pandjaitan, P. B., \& Hatta, M. (2013). Etnobotani dan Tumbuhan Berguna di Cagar Alam Dungus Iwul Bogor. Nusa Sylva, 13(2), 56-65. Retrieved from https://media.neliti.com/media/publications/236008-etnobotani-dan-tumbuhan-bergunadi-cagar-f28ef000.pdf

Mertha, I. G., Idrus, A. Al, Ilhamdi, M. L., \& Zulkifli, L. (2018). Pelatihan Teknik Pembuatan Herbarium Kering dan Identifikasi Tumbuhan Berbasis Lingkungan Sekolah di SMAN 4 Mataram. Jurnal Pendidikan Dan Pengabdian Masyarakat, 1(1), 82-87.

Nisyaputri, F. F., Iskandar, J., \& Partasasmita, R. (2018). Studi Etnobotani Tumbuhan Obat di Desa Wonoharjo , Kabupaten. Prosiding Masy Biodiv Indo, 4,
$122-132$.

https://doi.org/10.13057/psnmbi/m040205

Nurfadila, Iqbal, M., \& Pitopang, R. (2019). Kajian Etnobotani Pandanaceae Pada Suku Moma Di Ngata Toro, Kulawi, Sulawesi Tengah. Natural Science: Journal of Science and Technology, 8(1), 36-43. https://doi.org/10.22487/25411969.2019.v8.i1.126 34

Suminar, A. R., Herlambang, Y., \& Syarif, E. B. (2018). Perancangan Produk Herbarium sebagai Fitur Saung di Taman Wisata Alam Situ Patenggang. E-Proceeding of Art \& Design, 5(3), 3944-3951. Retrieved from https://openlibrary.telkomuniversity.ac.id/pustaka/files/146737/jurnal_eproc/peranc angan-produk-herbarium-sebagai-fitur-saung-di-taman-wisata-alam-situ-patenggang.pdf

Tamin, R. P., Anggraini, R., \& Ulfa, M. (2017). Penyuluhan dan Pelatihan Eksplorasi Botani Hutan dalam Upaya Konservasi Hutan. Karya Abdi Masyarakat, 1(2), 119-128.

https://doi.org/https://doi.org/10.22437/jkam.vli2.4 290. 